\title{
IN VITRO CYTOTOXIC STUDY OF GREEN SYNTHESIZED GOLD AND SILVER NANOPARTICLES USING ECLIPTA PROSTRATA (L.) AGAINST HT-29 CELL LINE
}

\author{
ARVINDGANTH RAJASEKAR $\$$, VARDHANA JANAKIRAMAN $\$$, KATHIRAVAN GOVINDARAJAN* \\ Department of Biotechnology, VISTAS, Vels University, Chennai, Tamil Nadu, India. Email: kathir14journals@gmail.com
}

Received: 07 June 2016, Revised and Accepted: 10 June 2016

\section{ABSTRACT}

Objective: The objective of this study is to synthesize gold and silver nanoparticles using the extracts of Eclipta prostrata.

Methods: The nanoparticles synthesize is carried out using the powdered leaves and mixed with distilled water. The filtered extract was then mixed with aqueous solution of $\mathrm{HAuCl}_{4}(1 \mathrm{mM})$ and $\mathrm{AgNo}_{3}(1 \mathrm{mM})$, and the reaction volume was made up to $100 \mathrm{ml}$. Then, the characterization of nanoparticles was carried out using ultraviolet, infrared, scanning electron microscope, and the cytotoxic activity of the nanoparticles were investigated against HT29 cancer cell lines.

Results: From the study, it was found that the plant extract was able to synthesize nanoparticles, and the synthesized nanoparticles were found to be toxic against the cancer cell line HT-29.

Conclusion: In the present study, both silver and gold nanoparticles were synthesized using the plant extract of E. prostrata. The synthesized nanoparticles were found to be effective against HT 29 cancer cells. The green synthesized nanoparticles were found to be cost-effective, simpler and environmentally safe. As the nanotechnology is an emerging field in medicine, the biological synthesis of nanoparticles helps in the other way. From the present study, the nanoparticles synthesized were thus proved against various studies novely. Hope this paves way for the better development of nanoparticle production in the large scale amount.

Keywords: Nanoparticles, Eclipta prostrata, Scanning electron microscope, HT-29 cell line.

\$Both authors are equally contributed

(C) 2016 The Authors. Published by Innovare Academic Sciences Pvt Ltd. This is an open access article under the CC BY license (http://creativecommons. org/licenses/by/4. 0/) DOI: http://dx.doi.org/10.22159/ajpcr.2016.v9i5.13194

\section{INTRODUCTION}

Nanobiotechnology involves a major role for nanometal studies [1] Metal science has its applications in various fields of modern science and technology [2]. Nanobiotechnology is currently fast growing technology, and there is a need to develop ecofriendly and environmental approaches. The biological synthesis of nanoparticles has been investigated by chemical and physical methods $[3,4]$. Biologically, synthesized gold nanoparticles have many applications in biomedical science drug delivery system, tissue engineering, and immune-chromatographic identification of pathogens in clinical specimens $[5,6]$. The recent study of silver nanoparticles reveals many applications, as it is spectrally selected for solar energy absorption, as intercalation material for electrical batteries, as optical receptors, as catalysts in chemical reactions, as antimicrobial and in biotabling $[7,8]$, due to the recent increasing awareness of green chemistry. Green chemistry is one of the key successes for nanoscience research [9]. Green nanoparticle synthesis and preparation are environmentally needed to grow metal nanoparticles [10]. Nanoparticles do not use toxic chemicals in the synthesis process to avoid effects in medical applications [11]. Both $\mathrm{Au}$ and Ag nanoparticles are the major leading powerful nanomaterials, providing an excellent platform in biological research and biomedical applications [12]. Cancer is one of the leading causes of death worldwide after cardiovascular diseases. Clinical trials and modern biomedical researchers can be achieved by so many ways for cancer treatment. However, the new therapeutic agents are needed with more active and fewer side effects.

Throughout the study biosynthesis of gold and silver nanoparticle synthesis using Eclipta prostrata extract. The stability of Au and AgNPs was evaluated and characterized by ultraviolet-visible (UV-vis) spectroscopy, scanning electron microscope (SEM), and Fourier transforms infrared (FTIR) analysis. The cytotoxicity study was performed against HT-29 cell line.

\section{MATERIALS AND METHODS}

The healthy fresh leaves of $E$. prostrata were collected from a Vellore hills and were placed in sterile zip-lock plastic bags [13]. $\mathrm{HAuCl}_{4}$ and $\mathrm{AgNO}_{3}$ were obtained from Sigma. Cell lines were obtained from the center for cell sciences, Pune, India.

\section{Preparation of plant extract}

The matured collected leaves were washed with double distilled water and were shadow dried. After drying, the E. prostrata leaves were grinded and to fine powder. $5 \mathrm{~g}$ of leaf powder was mixed with $100 \mathrm{ml}$ of distilled water, and the mixture was left in orbital shaking incubator at $1500 \mathrm{rpm}, 25^{\circ} \mathrm{C}$ for $74 \mathrm{hrs}$. Then, the extract was filtered and stored in airtight container.

\section{Synthesis of gold and silver nanoparticles}

The $10 \mathrm{ml}$ of the filtered extract of E. prostrata was mixed with aqueous solution of $\mathrm{HAuCl}_{4}(1 \mathrm{mM})$ and $\mathrm{AgNo}_{3}(1 \mathrm{mM})$, and the reaction volume was made up to $100 \mathrm{ml}$. The mixture solution was left on constant magnetic stirring at room temperature.

\section{Characterization of nanoparticles}

$U V$-vis absorbance spectral analysis

UV-vis spectral analysis was done using a Beckman DU-20 spectrophotometer. The metal reduction of $\mathrm{Au}$ and $\mathrm{Ag}$ ions was monitored by measuring UV-vis spectrum of the reaction medium at $72 \mathrm{hrs}$.

\section{FTIR spectroscopy}

FTIR analysis was done using Perkin Elmer spectrum-1, and it is used to analyze and identify the chemical constituents in the Mid Infrared region $400-4000 / \mathrm{cm}$ of the Au and AgNPs from plant extract. 
SEM

SEM analysis was done by following features detectors secondary electron, EDX: Peltier cooled X-ray head (Thermo, USA), resolution: 3 nm @3kV HV mode and 10 nm @ 3 kV HV mode (Hitachi s - 3400 N). For SEM, the nanoparticle synthesized was allowed to dry completely and grounded well to a powder. Since the specimen is at high vacuum, living cells and tissues, and whole, soft-bodied organisms usually require chemical fixation to preserve and stabilize. Fixation is usually performed by incubation in a solution of a buffered chemical fixative such as glutaraldehyde [14].

\section{In vitro cytotoxicity analysis}

Colon cancer - HT-29 and Normal VERO cell lines were obtained from the National Centre for Cell Sciences, Pune. The cells were maintained in minimal essential media supplemented with $10 \%$ fetal bovine serum penicillin $(100 \mathrm{U} / \mathrm{ml})$, and streptomycin $(100 \mu \mathrm{g} / \mathrm{ml})$ in a humidified atmosphere of $50 \mu \mathrm{g} / \mathrm{ml} \mathrm{CO} 2$ at $37^{\circ} \mathrm{C}$. In vitro assay for cytotoxicity activity (MTT assay) E. prostrata extract. The cytotoxicity of samples on HT-29 and VERO were determined by the MTT assay [15]. Cells (1×10/well) were plated in $1 \mathrm{ml}$ of medium/well in 24-well plates (Costar Corning, Rochester, NY). After $48 \mathrm{hrs}$ incubation, the cell reaches the confluence. Then, cells were incubated in the presence of various concentrations of the samples in $0.1 \%$ dimethyl sulfoxide for $48 \mathrm{hrs}$ at $37^{\circ} \mathrm{C}$. After removal of the sample solution and washing with phosphatebuffered saline (pH 7.4), $200 \mu \mathrm{l} /$ well $(5 \mathrm{mg} / \mathrm{ml}$ ) of $0.5 \%$ 3-(4,5-Dimethyl2-thiazolyl)-2,5-diphenyl-2H-tetrazolium bromidecells (MTT) phosphate-buffered saline solution was added. After 48 hrs incubation $0.04 \mathrm{M} \mathrm{HCl} /$ isopropanol was added. Viable cells were determined by the absorbance at $570 \mathrm{~nm}$. Measurements were performed, and the concentration required for a $50 \%$ inhibition of viability $\left(\mathrm{IC}_{50}\right.$ ) was determined graphically. The absorbance at $570 \mathrm{~nm}$ was measured with the UV-spectrophotometer using wells without sample containing cells as blanks. The effect of the samples on the proliferation of HT-29 and VERO were expressed as the \% cell viability using the following formula.

$\%$ cell viability $=$ A570 of treated cells $/$ A570 of control cells $\times 100 \%$

To examine the cytotoxic activity of Au and AgNPs against HT-29 human cancer cell line.

\section{RESULTS AND DISCUSSION}

Nanoparticles, which are prepared using E. prostrata extract as reducing agents, were collected, and nanoparticles were then subjected for analysis using different analytical and non-analytical methods. In this present study, nanoparticle synthesis was confirmed by various methods such as UV-vis spectroscopy, FTIR spectroscopy, SEM, and in vitro cytotoxicity analysis of gold and silver nanoparticles.

\section{UV-vis spectra of gold and silver nanoparticles}

The biosynthesis of the reduced metal nanoparticles (Au and AgNPs) was obtained and monitored by UV-vis spectrophotometer analysis. Gold and silver nanoparticles synthesis is confirmed by the maximum absorption range of $500-600 \mathrm{~nm}$ and $400-450 \mathrm{~nm}$, respectively (Figs. 1 and 2). For gold nanoparticles, the maximum absorption was found at around $530 \mathrm{~nm}$ and for silver nanoparticles absorption was marked at around $415 \mathrm{~nm}$.

\section{FTIR analysis}

FTIR study was analyzed and possible to identify the biomolecules which shows reduction of metal nanoparticles synthesis of FTIR spectra of nanoparticles thus obtained by biomolecular reduction process using E. prostrata extract are as follows (Figs. 3 and 4). It shows various peaks, stretching, and bending can be assigned to different functional groups.

The presence of peaks above $3000 / \mathrm{cm}$ indicates the existence of $\mathrm{OH}$ and NH groups. Peaks at 1,611,1,344, 1,242 in the data accounts for the existence of C-0 stretching. The aromatic nuclei are further confirmed by the peaks at 1,611, 1,069 in the fingerprint region due to out of

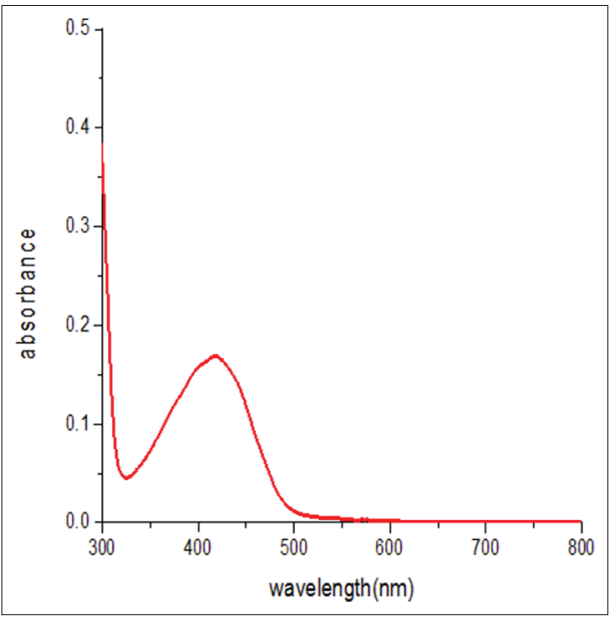

Fig. 1: Peaks at $415 \mathrm{~nm}$ indicate the presence on AgNP

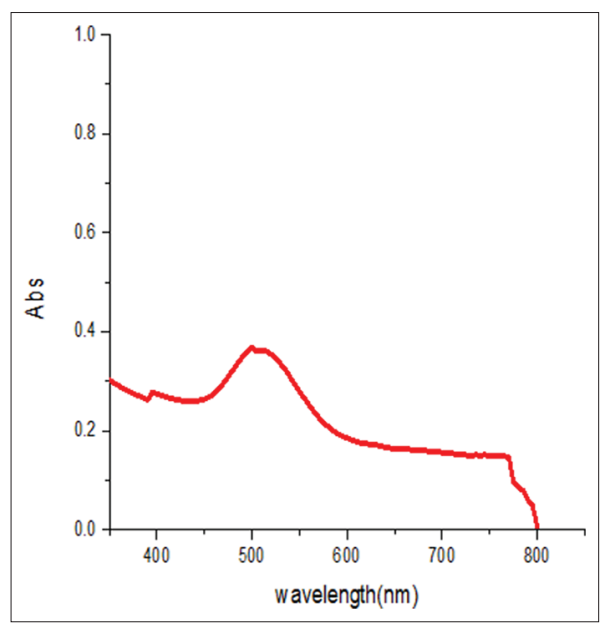

Fig. 2: Peak at $530 \mathrm{~nm}$ indicates the presence of AuNP

plane (OOP) bending vibration. The peaks above $3000 / \mathrm{cm}$ indicate the presence of $\mathrm{OH}$ and $\mathrm{NH}$ groups [16]. The existence of aromatic compound can also be further confirmed by the peak $1462 / \mathrm{cm}$ in IR spectra. The extracted compound should be a carbonyl compound due to the presence of peak in $1730 / \mathrm{cm}$, in IR spectra. Peaks at $1378 / \mathrm{cm}$ and $1274 / \mathrm{cm}$ in the IR data accounts for the existence of C-O stretching. The existence of aromatic nuclei is further confirmed by the peaks at $1,123,1,072$ in the fingerprint region due to OOP bending vibration. Further, the presence of alkyl groups, to which the aromatic moiety associates s confirmed by the groups of peaks at 2956, 2,925, 2,855 due to $\mathrm{sp}^{3}$ hybridized C-H stretching vibration of alkyl groups. Since there are no peaks above $3000 / \mathrm{cm}$, the possibility of the existence of $\mathrm{OH}$ and $\mathrm{NH}$ group is ruled out [16].

From the FTIR spectra, it is concluded that the synthesis of nanoparticles did not disturb the proteins present in the plant extract.

\section{SEM analysis}

The plant extracts treated with gold and silver nanoparticles were selected and characterized using SEM. The nanoparticles synthesized were spherical in shape. The size of the gold nanoparticle was ranging from 47 to $92 \mathrm{~nm}$, and the size of the silver nanoparticle was ranging from 32 to $81 \mathrm{~nm}$ (Figs. 5 and 6). From the SEM study, it is confirmed that the plant extracts are capable of synthesizing the desired nanoparticles.

\section{In vitro cytotoxicity analysis}

The cytotoxicity study of gold and silver nanoparticles was using E. prostrata against HT-29 cell line. The cells were examined in terms 


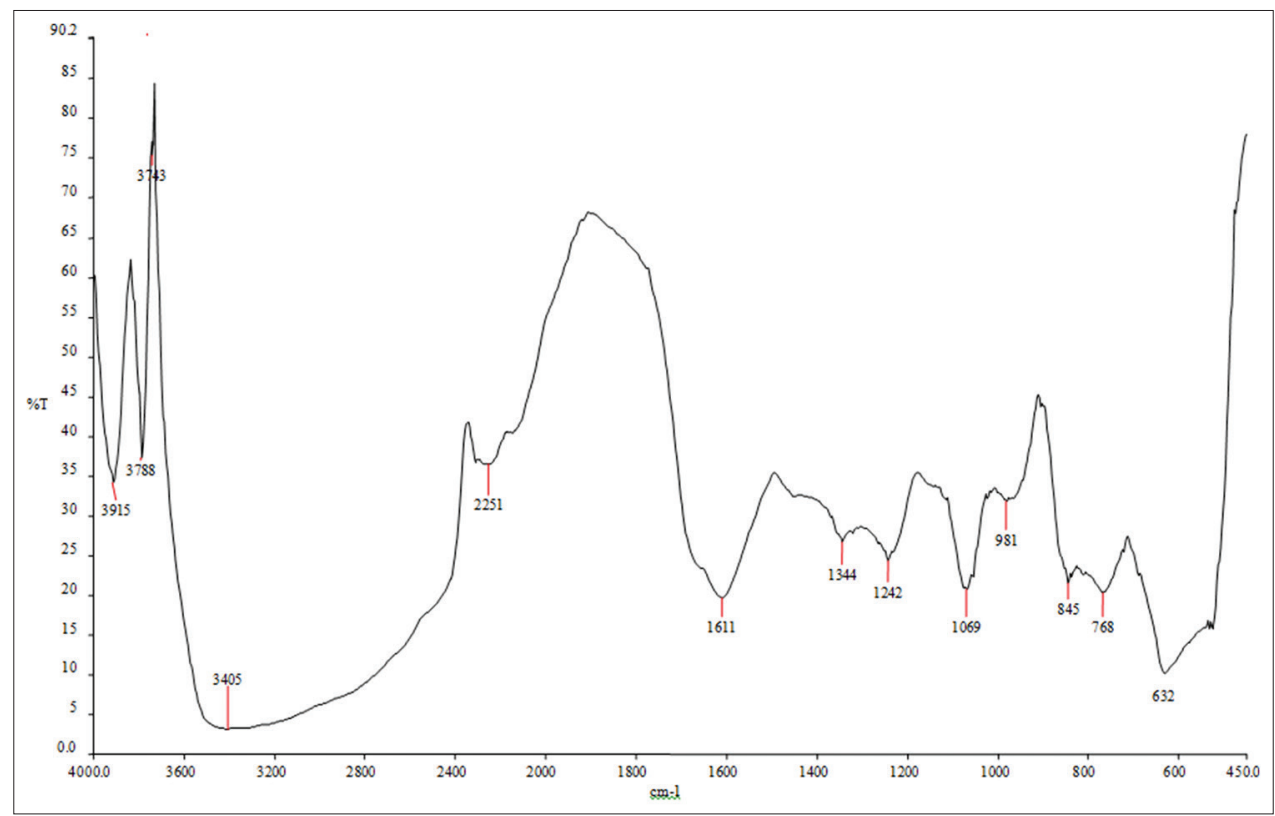

Fig. 3: FTIR spectra of the silver nanoparticles synthesized from the extract of Eclipta prostrata

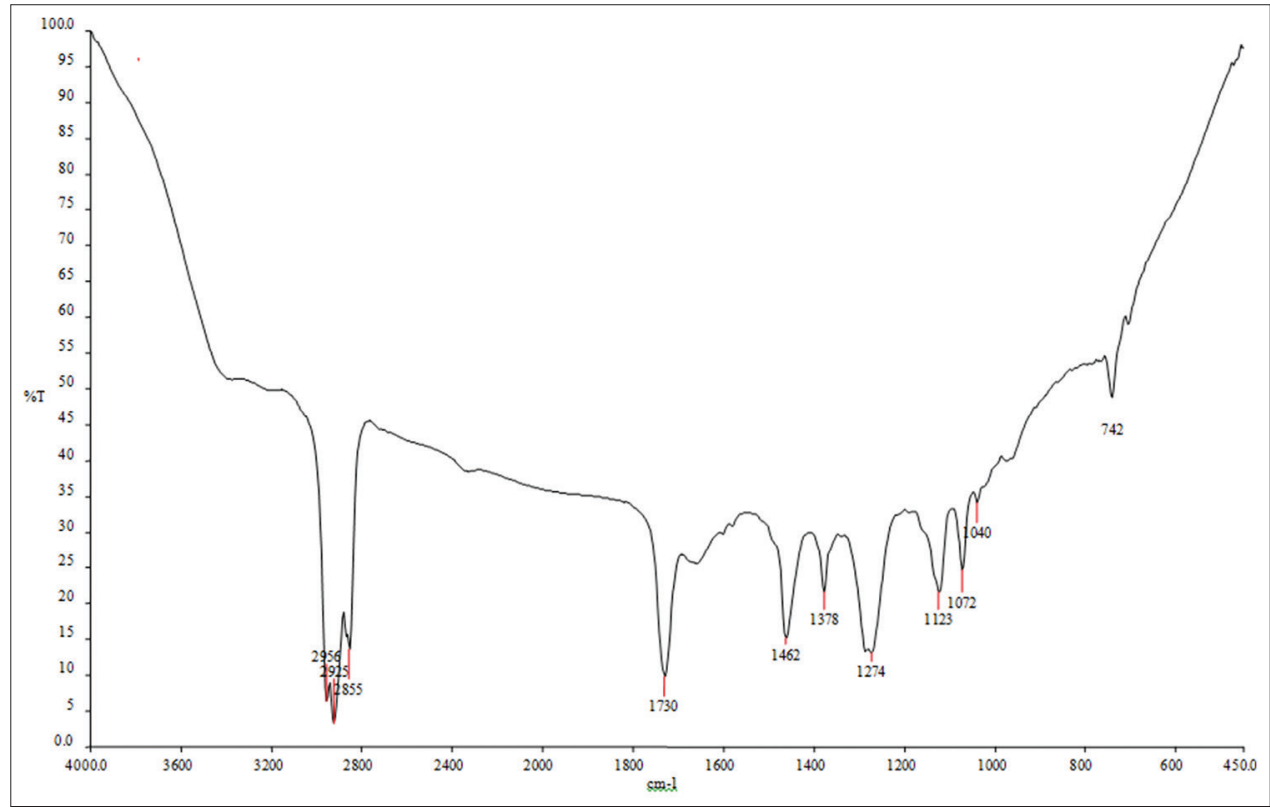

Fig. 4: Fourier transforms infrared spectra of the gold nanoparticles synthesized from the extract of Eclipta prostrata

of the effect of Au and AgNPs on cell toxicity by MTT assay for $24 \mathrm{hrs}$. After the treatment of Au and AgNPs, the cellular morphologies of cell line shows cytotoxicity effect causing significant cell damage or death of the treated cell lines (HT-29). After 24 hrs of incubation, the cell death was observed more in the concentration of $100 \mu \mathrm{l}$ of Ag and AuNPs (Figs. 7 and 8).

\section{DISCUSSION}

In modern science, biomedical technology is well developed and growing in recent times. Biological synthesis of metal nanoparticles is an important role in the field of modern nanotechnology. Green synthesis of nanomedicine plays key role in bio Medical science. In this study, biological synthesis of gold and silver nanoparticle using E. prostrata, and their cytotoxic study is taken into consideration. The nanoparticles both Au and AgNPs obtained are characterized by UV-vis spectroscopy, SEM $[17,18]$. The functional groups of the gold and silver nanoparticles in E. prostrata leaf extract were characterized by FTIR Fourier Transform Infrared spectroscopy. The in vitro cytotoxicity analysis of $\mathrm{Au}$ and $\mathrm{Ag}$ nanoparticles showed good cytotoxic activity against HT-29 cell line. From this study, it is found that the biomedical properties are present in $\mathrm{Au}$ and $\mathrm{Ag}$ nanoparticles.

\section{CONCLUSION}

In the present study, both silver and gold nanoparticles were synthesized using the plant extract of E. prostrata. The synthesized nanoparticles were found to be effective against HT-29 cancer cells. The green synthesized nanoparticles were found to be cost-effective, simpler, and environmentally safe. As the nanotechnology is an emerging field in medicine, the biological synthesis of nanoparticles helps in the other way. From the present study, the nanoparticles 


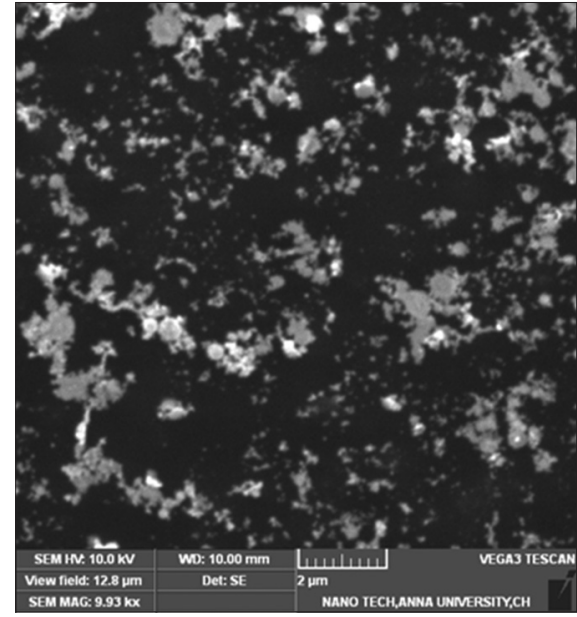

Fig. 5: Scanning electron microscope image of gold nanoparticle

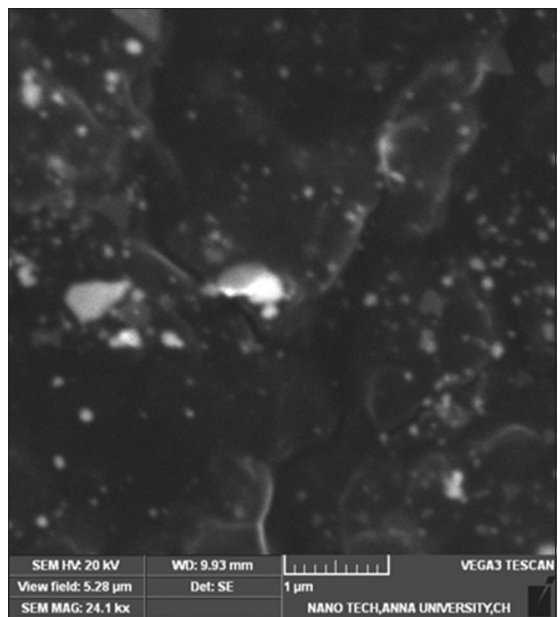

Fig. 6: Scanning electron microscope image of silver nanoparticle

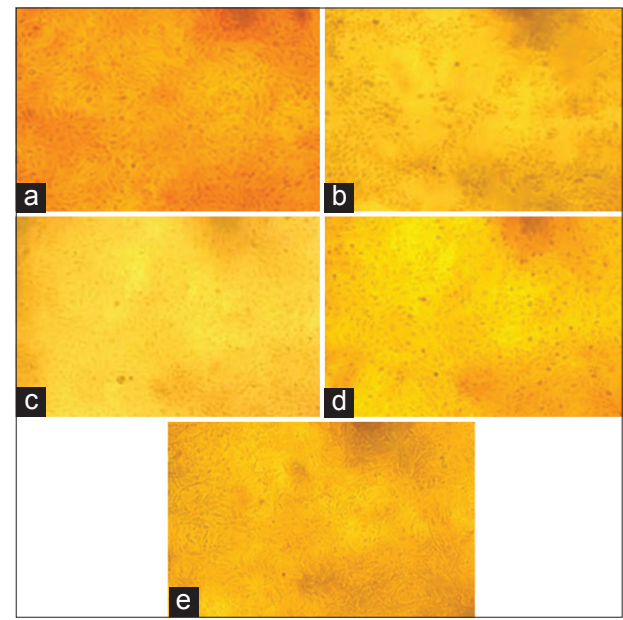

Fig. 7: Effect of gold and silver nanoparticles on VERO cell lines

(a) Normal VERO cell line, (b) toxicity - $25 \mu \mathrm{g} / \mathrm{ml}$, (c) toxicity $50 \mu \mathrm{g} / \mathrm{ml}$, (d) toxicity - $75 \mu \mathrm{g} / \mathrm{ml}$, (e) toxicity - $100 \mu \mathrm{g} / \mathrm{ml}$

synthesized were thus proved against various studies novely. Hope this paves way for the better development of nanoparticle production in the large scale amount.
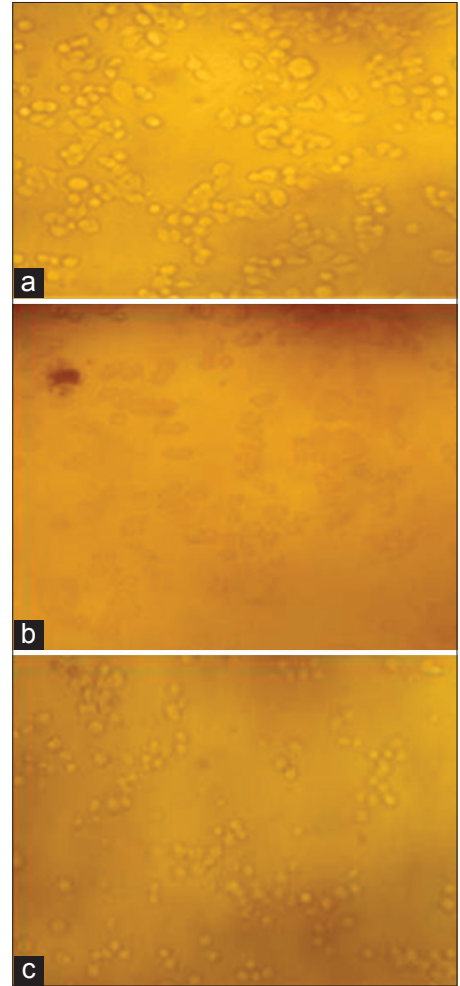

Fig. 8: Effect of gold and silver nanoparticles against HT-29 cell lines. (a) Normal HT-29 cell line, (b) toxicity of AgNPs at $100 \mu \mathrm{g} / \mathrm{ml}$, (c) toxicity of AuNPs at $100 \mu \mathrm{g} / \mathrm{ml}$

\section{ACKNOWLEDGMENT}

The authors thank CNST, Anna University, Chennai, for proving the instrumentation facility.

\section{REFERENCES}

1. Gericke M, Pinches A. Biological synthesis of metal nanoparticles. Hydrometallury 2006;83:132-40.

2. Hamilton JF, Baetzold RC. Catalysis by small metal clusters. Science 1979;205(4412):1213-20.

3. Henglein, A, Electronics of coloidall nanometer Bunseng Ber Phys Chem 1995;99:903-13.

4. Daniel MC, Astruc D. Gold nanoparticles: Assembly, supramolecula chemistry, quantum-size-related properties, and applications toward biology, catalysis, and nanotechnology. Chem Rev 2004;104(1):293-346.

5. Fadeel B, Bennett AE. Better safe than sorry: Understanding the toxicological properties of inorganic nanoparticles manufactured for biomedical applications. Adv Drug Deliv Rev 2010;62:362-74.

6. Tomar A, Garg G. Short review on application of gold nanoparticles Glob J Pharmacol 2013;7:34-8.

7. Dimitrijevic NM, Bartels DM, Jonah CD, Takahashi K, Rajh T Radiolytically induced formation and optical absorption spectra of colloidal silver nanoparticles in supercritical ethane. J Physchem B 2010;105:954-9.

8. Mandal D, Bolander ME, Mukhopadhyay D, Sarkar G, Mukherjee P. The use of microorganisms for the formation of metal nanoparticles and their application. Appl Microbiol Biotechnol 2006;69(5):485-92.

9. Chandran SP, Chaudhary M, Pasricha R, Ahmad A, Sastry M. Synthesis of gold nanotriangles and silver nanoparticles using Aloe vera plant extract. Biotechnol Prog 2006;22(2):577-83.

10. Shah ZA, Vohora SB. Antioxidant/restorative effects of calcined gold preparations used in Indian systems of medicine against global and focal models of Ischemia. Pharmacol Toxicol 2002;90(5):254-9.

11. Shah ZA, Gilani RA, Sharma P, Vohora SB. Attenuation of stress - Elicited brain catecholamines, serotonin and plasma corticosterone levels by calcined gold preparations used in Indian system of medicine. Basic Clin Pharmacol Toxicol 2005;96:469-4. 
12. Akinyanju JA, Fadayomi O. Effect of divron on surgarcane shizosphere microbial population. Niger J Bot 1989;2:49-58.

13. Bharathidasan R, Panneerselvam A. Biosynthesis and charac-terization of silver nanoparticles using endophytic fungi Aspergillus concius, Penicillium janthinellum and Phomosis sp Sp. Int J Pharm Sci Res 2012;3(9):3163-9.

14. Sanghi R, Verma P. Biomimetic synthesis and characterisation of protein capped silver nanoparticles. Bioresour Technol 2009;100(1):501-4.

15. Mosmann T. Rapid colorimetric assay for cellular growth and survival application to proliferation and cytotoxicity assays. J Immunol Met $1983 ; 65: 55-63$.
16. Krishnaraj C, Muthukumaran P, Ramachandran R, Balakumaran MD, Kalaichelvan PT. Acalypha indica Linn: Biogenic synthesis of silver and gold nanoparticles and their cytotoxic effects against MDAMB-231, human breast cancer cells. Biotechnol Rep 2014;4:42-9.

17. Rebecca T, Sourabh M, Janhavi M, Pooja J. Synthesis of silver nanoparticles and its cytotoxic effect against thp-1 cancer cell line. Int J Pharm Bio Sci 2013;4(1):184-92.

18. Sujitha MV, Soundarapandian K. Green synthesis of gold nanoparticles using Citrus fruits (Citrus limon, Citrus reticulate and Citrus sinensis) aqueous extract and its characterization. Spectrochim Acta A Mole Biomole Spectrosc 2013;102:15-23 